\title{
$\beta$-Galactoside Transport in an Alkaline-tolerant Strain of Bacillus circulans
}

\author{
By ARTHUR A. GUFFANTI, LOUIS G. MONTI, ROBERT BLANCO, \\ DANIEL OZICK AND TERRY A. KRULWICH \\ Department of Biochemistry, Mount Sinai School of Medicine of the City University \\ of New York, New York 10029, U.S.A.
}

(Received 1 August 1978; revised 4 October 1978)

\begin{abstract}
An alkaline-tolerant bacterium, which grew on various carbohydrates between $\mathrm{pH} 6$ and 9.5, was isolated from soil and identified as Bacillus circulans. Lactose-grown organisms exhibited a transmembrane $\mathrm{pH}$ gradient $(\Delta \mathrm{pH})$ of $-47 \mathrm{mV}$ at $\mathrm{pH} 6 \cdot 6$, but no $\Delta \mathrm{pH}$ at $\mathrm{pH} 9 \cdot 0$. The transmembrane electrical potential $(\Delta \psi)$ was $-66 \mathrm{mV}$ at $\mathrm{pH} 6.6$ and $-115 \mathrm{mV}$ at $\mathrm{pH} 9.0$. Thus the total protonmotive forces at the two $\mathrm{pH}$ values were essentially the same. Lactose-grown organisms transported thiomethyl $\beta$-D-galactopyranoside (TMG) at $\mathrm{pH} 6.6$ and at $\mathrm{pH} 9 \cdot 0$, but transport at the alkaline $\mathrm{pH}$ was dependent upon addition of ascorbate/ $N, N, N^{\prime}, N^{\prime}$-tetramethyl-p-phenylenediamine (TMPD) or preincubation with lactose. In the presence of ascorbate/TMPD, the TMG transport system exhibited similar kinetics and

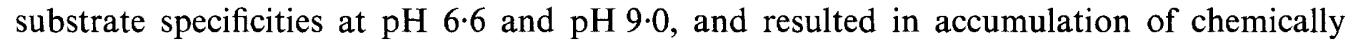
unmodified TMG to a concentration approximately 180 times greater than the external concentration. Experiments in which a diffusion potential was generated in starved organisms or in which organisms were treated with nigericin indicated a lack of correlation between the rate of TMG uptake and the magnitude of $\Delta \psi$. By contrast, the rate of TMG uptake correlated with cellular ATP levels in organisms incubated at different $\mathrm{pH}$ values and in organisms treated with $N, N^{\prime}$-dicyclohexylcarbodiimide, arsenate or nigericin.
\end{abstract}

\section{INTRODUCTION}

Bacterial processes such as motility (Larsen et al., 1974; Thipoyathasana \& Valentine, 1974), active transport (Kashket \& Wilson, 1974; Pavlasova \& Harold, 1968; West \& Mitchell, 1972) and ATP synthesis (Maloney et al., 1974; Tsuchiya \& Rosen, 1976; Tsuchiya, 1977) depend on the presence of an activated membrane state. It is now generally believed that the activated state of the membrane consists of a protonmotive force (p.m.f; Mitchell, 1961, 1963). According to Mitchell's chemiosmotic hypothesis, the p.m.f. is generated by the extrusion of protons during the oxidation of substrates via the respiratory chain and during ATP hydrolysis. This results in the acidification of the external milieu, generating a $\mathrm{pH}$ gradient across the cell membrane $(\Delta \mathrm{pH}$, interior alkaline). Moreover, the unequal distribution of protons results in the establishment of a transmembrane electrical potential ( $\Delta \psi$, interior negative). Indeed, the extrusion of protons has been shown to occur when substrates are oxidized by the respiratory chain (Hertzberg \& Hinkle, 1974; Scholes \& Mitchell, 1970) or on hydrolysis of ATP by bacterial $\left(\mathrm{Ca}^{2+}, \mathrm{Mg}^{2+}\right)$-ATPase (Hertzberg \& Hinkle, 1974; West \& Mitchell, 1974). Synthesis of ATP occurs in response to either a $\Delta \mathrm{pH}$ or a $\Delta \psi$ of sufficient magnitude (Wilson et al., 1976), and various respiration-coupled transport systems have been shown to respond directly to either the $\Delta \mathrm{pH}$ or the total p.m.f. (Flagg \& Wilson, 1977; Ramos \& Kaback, $1977 a, b$ ). Another category of active transport systems, usually lost on osmotic shock, are believed to be coupled in some direct way to the phosphate bond energy of ATP (Berger, 1973; Berger \& Heppel, 1974; Klein \& Boyer, 1972). 
The ATP can be produced from glycolysis, but in aerobes would primarily arise from the vectorial action of a p.m.f. on the membrane-bound ATPase.

Can an organism which grows in an alkaline environment utilize a p.m.f. generating a large enough electrical potential to compensate for the lack of a proton gradient or even a 'reversed' $\Delta \mathrm{pH}$ ? Or will such an organism subsist on the ATP produced fermentatively, and utilize a phosphotransferase system and/or ATP-dependent transport mechanisms for solute transport? In an attempt to answer these questions, work was initiated on alkalophilic and alkaline-tolerant Bacillus species. In a truly alkalophilic species, Bacillus alcalophilus, growth on L-malate and transport of $\alpha$-aminoisobutyric acid (AIB) occurred at $\mathrm{pH}$ values up to 11.5 and were optimal at $\mathrm{pH} 10 \cdot 5$. In that highly alkaline $\mathrm{pH}$ range, $B$. alcalophilus maintained a large $\Delta \mathrm{pH}$, interior acid. While the $\Delta \psi$ was also large, and increased with increasing $\mathrm{pH}$, the total p.m.f. was very low. Transport of AIB occurred by electrogenic symport with sodium ions in response to the $\Delta \psi$ (Guffanti et al., 1978). The studies reported here were conducted on a newly isolated, alkaline-tolerant strain of Bacillus circulans. This obligate aerobe grew in media ranging from $\mathrm{pH} 6$ to $9 \cdot 5$. At the lower end of its $\mathrm{pH}$ range, both a $\Delta \mathrm{pH}$ and $\Delta \psi$ were demonstrable. At the higher $\mathrm{pH}$ values, $\Delta \mathrm{pH}$ was zero (but not 'reversed') and $\Delta \psi$ was significantly higher than at lower $\mathrm{pH}$ values. Studies of $\beta$-galactoside transport indicated that ATP is directly involved in the energization of this transport system.

\section{METHODS}

Organism and growth conditions. A bacterium which was able to tolerate alkaline $\mathrm{pH}$ was isolated from soil by enrichment culture techniques, using sequential transfers in liquid medium and final single colony isolation from solid medium. The medium employed for enrichment as well as for subsequent growth and maintenance contained $25 \mathrm{mM}$-Tris, $25 \mathrm{~mm}$-potassium phosphate, $7.6 \mathrm{~mm}-\left(\mathrm{NH}_{4}\right)_{2} \mathrm{SO}_{4}$ and $0.1 \mathrm{~mm}-\mathrm{MgSO}_{4}$, adjusted to $\mathrm{pH} 9 \cdot 0$. This basal medium, referred to as PT9, was completed by the aseptic addition of sterile solutions of trace salts (Hegeman, 1966) to a final concentration of $1 \%(\mathrm{v} / \mathrm{v}), 0.1 \%(\mathrm{w} / \mathrm{v})$ yeast extract and carbon source ( $25 \mathrm{~mm}$ for disaccharides, $50 \mathrm{~mm}$ for monosaccharides). An identical medium, adjusted to $\mathrm{pH} 6.6$ is referred to as PT6.6. Lactose was the carbon source used for enrichment and for most of the experiments described here. Organisms were grown at $30^{\circ} \mathrm{C}$ on a New Brunswick G25 rotatory shaker with continuous shaking at $200 \mathrm{rev} . \mathrm{min}^{-1}$. Growth was monitored turbidimetrically with a Klett-Summerson colorimeter (no. 42 filter). The ability of the organism to grow was determined as a function of pH. Since PT9 became somewhat more acid even when the buffer concentration was doubled, only the initial growth rate was used. The organism grew well between $\mathrm{pH} 6.5$ and 9.5 with either lactose or glucose as the carbon source.

Identification of the alkaline-tolerant organism. The bacterium isolated at high $\mathrm{pH}$ was an aerobic, rodshaped, Gram-positive, peritrichously flagellated, spore-forming organism identified as Bacillus circulans on the basis of its morphological and physiological characteristics (Buchanan \& Gibbons, 1974; Gordon et al., 1973). It appeared to have amounts of loose capsular material adhering to its surface. The $\mathrm{G}+\mathrm{C}$ content, as estimated by the temperature melt method of Marmur \& Doty (1959), was $50.5 \%$ when determined on DNA extracted by the method of Marmur (1961). In media with $\mathrm{NH}_{4}{ }^{+}$as nitrogen source and adjusted to $\mathrm{pH} 9$ or $\mathrm{pH} 6 \cdot 6$, the organism grew on carbohydrates such as arabinose, fructose, galactose, gluconate, glucose, glycerol, lactose, maltose, mannitol, mannose, rhamnose, sucrose or xylose. Organic acids and amino acids were not utilized as carbon sources.

Chemicals. Lysozyme (EC 3.2.1.17; egg white), $N, N$-dicyclohexylcarbodiimide (DCCD), $N, N, N^{\prime}, N^{\prime}-$ tetramethyl- $p$-phenylenediamine (TMPD), isopropyl $\beta$-D-thiogalactoside (IPTG), $o$-nitrophenyl $\beta$-D-galactoside (ONPG), firefly tails, ATP (disodium salt) and chloramphenicol were obtained from Sigma. Valinomycin was purchased from Calbiochem. Amersham-Searle provided $4-O-\beta$-D-galactopyranosyl-D- $\left[1-{ }^{14} \mathrm{C}\right]-$ glucopyranose $\left(\left[{ }^{14} \mathrm{C}\right] \mathrm{lactose}\right)$ and New England Nuclear provided $\left[\mathrm{G}-{ }^{3} \mathrm{H}\right]$ inulin, $\left[{ }^{14} \mathrm{C}\right]$ methylamine hydro-

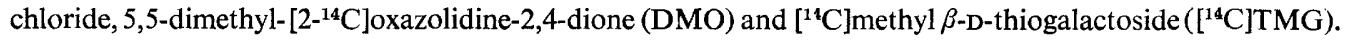
Nigericin and $\left[{ }^{3} \mathrm{H}\right]$ triphenylmethylphosphonium bromide (TPMP ${ }^{+}$) were generously provided by $\mathrm{Dr} \mathrm{H} . \mathrm{R}$. Kaback. All other chemicals were obtained commercially at the highest purity available.

Measurement of lactose and TMG uptake. Organisms growing exponentially on PT9 with lactose as carbon source were washed twice in PT basal medium of the appropriate $\mathrm{pH}$ and suspended in the same medium. Cell suspensions (about $0.1 \mathrm{mg}$ protein $\mathrm{ml}^{-1}$ ) were treated with chloramphenicol $\left(40 \mu \mathrm{g} \mathrm{ml}^{-1}\right)$ for $10 \mathrm{~min}$ at $25^{\circ} \mathrm{C}$ prior to uptake experiments. Either $20 \mu \mathrm{M}$ - $\left.{ }^{14} \mathrm{C}\right]$ lactose $\left(10 \mu \mathrm{Ci} \mu \mathrm{mol}^{-1}\right)$ or $200 \mu \mathrm{M}$ - $\left[{ }^{14} \mathrm{C}\right] \mathrm{TMG}$ $\left(0.33 \mu \mathrm{Ci} \mu \mathrm{mol}^{-1}\right)$ was added to aerated cells at $25^{\circ} \mathrm{C}$ to start the reaction. Suspensions were aerated by 
rapid stirring during the incubations with radioactive substrate. Samples $(1 \mathrm{ml})$ were taken at appropriate intervals, quickly filtered through Matheson-Higgins filters (pore size $0.45 \mu \mathrm{m}$ ) and washed with $10 \mathrm{ml}$ buffer. The filters were dried and placed in glass scintillation vials. Scintillation cocktail (10 ml Econofluor; New England Nuclear) was added to each vial, and radioactivity was measured with a Beckman LS-230 spectrometer.

Extraction and identification of accumulated TMG. Organisms were allowed to accumulate $\left[{ }^{14} \mathrm{C}\right] \mathrm{TMG}$ for $30 \mathrm{~min}$, after which they were centrifuged, washed and resuspended in $0.2 \mathrm{ml} 5 \%(\mathrm{v} / \mathrm{v})$ butanol, as described by Egan \& Morse (1966). The radioactive extract was spotted on Whatman no.1 filter paper and descending chromatography was performed with 1-butanol/acetic acid/water (2:1:1, by vol.; Winkler \& Wilson, 1966).

Determination of $\Delta p H$ and $\Delta \psi$. Intracellular water volume was determined by the method of Maloney et al. (1975), using $\left[{ }^{3} \mathrm{H}\right]$ inulin $\left(270 \mathrm{Ci} \mathrm{g}^{-1}\right)$. The internal water volume was calculated to be $3.4 \mu l$ (mg protein $)^{-1}$. Protein was determined by the method of Lowry et al. (1951), using lysozyme as a standard.

The $\Delta \mathrm{pH}$ was measured by uptake of a weak acid or weak base using flow dialysis in an apparatus modified according to Ramos et al. (1976). Organisms were washed twice in the appropriate basal medium (PT9 or PT6.6) and pretreated with $1 \mathrm{mm-EDTA}$ for $10 \mathrm{~min}$ in a variation of the method of Padan et al. (1976). The cells were then washed free of EDTA and resuspended (final concentration 10 to $15 \mathrm{mg}$ protein $\mathrm{ml}^{-1}$ ) in the upper chamber of the flow dialysis apparatus. The intracellular cell volume occupied 4 to $5 \%$ of the total volume of $800 \mu \mathrm{l}$ in the upper chamber. Either the weak acid $\left[{ }^{14} \mathrm{C}\right] \mathrm{DMO}\left(8.8 \mathrm{mCi} \mathrm{mmol}^{-1}\right)$ or the weak base $\left[{ }^{14} \mathrm{C}\right]$ methylamine $\left(52 \cdot 2 \mathrm{mCi} \mathrm{mmol}^{-1}\right)$ was added to a final concentration of $141 \mu \mathrm{M}$ or $53 \mu \mathrm{M}$, respectively. Flow dialysis was performed exactly as described by Ramos et al. (1976). Control experiments were carried out with heat-killed organisms to obtain values for non-specific binding of DMO or methylamine. In those experiments in which a $\Delta \mathrm{pH}$ was demonstrated using DMO, addition of $0 \cdot 2 \mu \mathrm{M}$-nigericin completely abolished DMO uptake. The internal pH was calculated according to the method of Waddell \& Butler (1959) and $\Delta \mathrm{pH}$ was expressed as the difference between internal and external $\mathrm{pH}$.

The electrical potential across the membrane was determined by measuring the accumulation of the lipophilic cation TPMP ${ }^{+}$, using a filtration assay (Schuldiner $\&$ Kaback, 1975). [ [ $\left.{ }^{3}\right] \mathrm{TFMP}^{+}\left(45 \mathrm{mCi} \mathrm{mmol}^{-1}\right)$ was added to a washed cell suspension $\left(0.1 \mathrm{mg}\right.$ protein $\left.\mathrm{ml}^{-1}\right)$ to a final concentration of $25 \mu \mathrm{M}$. Suspensions were gassed with water-saturated oxygen and steady-state concentration values from TPMP ${ }^{+}$uptake $^{-}$ experiments were used to calculate $\Delta \psi$ from the Nernst equation:

$$
\Delta \psi=58.8 \log \frac{\left[\mathrm{TPMP}^{+}\right]_{\text {in }}}{\left[\mathrm{TPMP}^{+}\right]_{\text {out }}}
$$

Values for non-specific binding were determined from zero-time points. The total p.m.f. was calculated by inserting the values for $\Delta \mathrm{pH}$ and $\Delta \psi$ into the equation: p.m.f. $=\Delta \psi-\mathrm{Z} \Delta \mathrm{pH}$.

Measurement of ATP. Exponentially growing organisms were washed with PT9 or PT6.6 and ATP was extracted with $30 \%(\mathrm{v} / \mathrm{v})$ perchloric acid according to the method of Cole et al. (1967). The ATP was measured by the firefly assay in a Beckman LS-230 spectrometer with the coincidence switch off, as described by Stanley \& Williams (1969). On each day a new ATP standard was determined and a fresh firefly lantern extract was prepared.

\section{RESULTS}

The p.m.f. was determined in organisms of the alkaline-tolerant $B$. circulans strain which had been grown on lactose at $\mathrm{pH} \mathrm{9.0,} \mathrm{then} \mathrm{washed} \mathrm{and} \mathrm{resuspended} \mathrm{at} \mathrm{pH} 6.6$ or $\mathrm{pH} 9 \cdot 0$. At $\mathrm{pH} 6 \cdot 6$, these organisms exhibited only a small $\Delta \mathrm{pH}$ which was increased by the addition of ascorbate/TMPD. No $\Delta \mathrm{pH}$ was observed at an external $\mathrm{pH}$ of 9.0 (Table 1). At more alkaline $\mathrm{pH}$ values, up to $\mathrm{pH} 10 \cdot 0$, the $\Delta \mathrm{pH}$ remained zero; no 'reversed' $\Delta \mathrm{pH}$ (i.e. interior acid) was found (data not shown). The $\Delta \psi$ was significantly higher at $\mathrm{pH} 9.0$ than at $\mathrm{pH} 6.6$, and was slightly elevated by the addition of ascorbate/TMPD at both $\mathrm{pH}$ values. Because of the higher $\Delta \psi$ at $\mathrm{pH} 9 \cdot 0$, the total p.m.f.s at the two $\mathrm{pH}$ values were not significantly different even though a $\Delta \mathrm{pH}$ was generated only at $\mathrm{pH} 6 \cdot 6$.

A study of $\beta$-galactoside transport by lactose-grown cells was then undertaken. Since the $B$. circulans strain used only carbohydrates for growth, we first investigated whether a phosphotransferase system might be employed for transport, thus circumventing the need for respiration-derived energy. All attempts to detect a phosphoenolpyruvate:hexose phosphotransferase system by the method of Tanaka et al. (1967) were negative.

In preliminary experiments, $B$. circulans took up TMG at $\mathrm{pH} 6.6$, but showed no TMG transport at alkaline $\mathrm{pH}$. Lactose accumulation was linear with time at $\mathrm{pH} 6 \cdot 6$, but at $\mathrm{pH} 9 \cdot 0$ 
Table 1. pH gradient and electrical potential across the membrane of lactose-grown $B$. circulans at $\mathrm{pH} 6.6$ and 9.0

Organisms grown on PT9/lactose were washed twice and resuspended in PT9 or PT6.6. $\Delta \mathrm{pH}$ and $\Delta \psi$ were measured in the absence or presence of $20 \mathrm{~mm}$-ascorbate plus $2 \mathrm{mM}$-TMPD (designated AT). The $\Delta \mathrm{pH}$ was determined by the distribution in flow dialysis of $\left[{ }^{14} \mathrm{C}\right] \mathrm{DMO}$ at $\mathrm{pH} 6.6$ and $9 \cdot 0$. $\left[{ }^{14} \mathrm{C}\right]$ Methylamine uptake was also assayed at $\mathrm{pH} 9 \cdot 0$. The membrane potential was measured by the accumulation of $\left[{ }^{3} \mathrm{H}\right] \mathrm{TPMP}+$.

\begin{tabular}{|c|c|c|c|c|c|c|c|c|}
\hline \multirow[b]{2}{*}{ External pH } & \multicolumn{2}{|c|}{ Internal $\mathrm{pH}$} & \multicolumn{2}{|c|}{$\Delta \mathrm{pH}(\mathrm{mV})$} & \multicolumn{2}{|c|}{$\Delta \psi(\mathrm{mV})$} & \multicolumn{2}{|c|}{ P.m.f. (mV) } \\
\hline & $\begin{array}{c}\text { Without } \\
\text { AT }\end{array}$ & $\begin{array}{l}\text { With } \\
\text { AT }\end{array}$ & $\begin{array}{c}\text { Without } \\
\text { AT }\end{array}$ & $\begin{array}{l}\text { With } \\
\text { AT }\end{array}$ & $\begin{array}{c}\text { Without } \\
\text { AT }\end{array}$ & $\begin{array}{l}\text { With } \\
\text { AT }\end{array}$ & $\begin{array}{l}\text { Without } \\
\text { AT }\end{array}$ & $\begin{array}{l}\text { With } \\
\text { AT }\end{array}$ \\
\hline $\begin{array}{l}6 \cdot 6 \\
9 \cdot 0\end{array}$ & $\begin{array}{l}7 \cdot 4 \\
9 \cdot 0\end{array}$ & $\begin{array}{l}7 \cdot 7 \\
9 \cdot 0\end{array}$ & $\begin{array}{r}-47 \\
0\end{array}$ & $\begin{array}{r}-71 \\
0\end{array}$ & $\begin{array}{r}-66 \\
-115\end{array}$ & $\begin{array}{r}-83 \\
-138\end{array}$ & $\begin{array}{l}-113 \\
-115\end{array}$ & $\begin{array}{l}-154 \\
-138\end{array}$ \\
\hline
\end{tabular}

the rate of accumulation increased dramatically with time. Preincubation $\left(30 \mathrm{~min}, 30^{\circ} \mathrm{C}\right)$ in PT9 containing $25 \mathrm{~mm}$-lactose abolished the accelerating kinetics at alkaline $\mathrm{pH}$. Addition of ascorbate/TMPD mimicked the effects of preincubation with lactose. In the presence of the artificial electron donor, the initial rate of lactose accumulation at alkaline $\mathrm{pH}$ was stimulated and the accelerating kinetics were abolished (Fig. 1). Moreover, in the presence of ascorbate/TMPD, TMG uptake was observed at $\mathrm{pH} 9 \cdot 0$. The initial rate of TMG uptake exhibited at $\mathrm{pH} 9.0$ in the presence of ascorbate/TMPD was the same as that found at pH 6.6 either with or without ascorbate/TMPD (Fig. 2). In most of the subsequent transport experiments, ascorbate/TMPD was included in the reaction mixtures.

Uptake of TMG was examined over a range of TMG concentrations from $1 \mu \mathrm{M}$ to $1 \mathrm{mM}$ at both $\mathrm{pH}$ values, but only one saturable system was observed. The apparent $K_{\mathrm{m}}$ at $\mathrm{pH} 9.0$ or 6.6 was 100 to $150 \mu \mathrm{M}$. When an external concentration of $200 \mu \mathrm{M}$-TMG was used and the steady-state level of TMG accumulation was measured in the presence of ascorbate/ TMPD, cells were found to concentrate TMG 185 -fold at $\mathrm{pH} 6.6$ and 175 -fold at $\mathrm{pH} 9.0$ over the concentration in the medium.

In initial determinations of the inhibition of TMG uptake by lactose, a stimulatory effect $(25 \%)$ was found at low lactose concentrations $(1 \mu \mathrm{M}, 2 \mu \mathrm{M})$, possibly due to inhibition of efflux. Inhibition of TMG uptake by higher concentrations of lactose (10 or $20 \mu \mathrm{M})$ was competitive, with an apparent $K_{\mathrm{i}}$ of $7.7 \mu \mathrm{M}$ (data not shown). Both IPTG and ONPG inhibited TMG uptake at pH 9.0 and 6.6 to approximately the same extent (Table 2). Galactose and melibiose also inhibited considerably when added at concentrations 10 times that of TMG. Other sugars tested showed less than $30 \%$ inhibition.

To eliminate the possibility that TMG was trapped inside the organisms by an enzymic conversion, organisms were allowed to accumulate the radioactively labelled analogue, and then excess non-radioactive TMG was added to half the suspension. The accumulated TMG was rapidly displaced (data not shown). Intracellular radioactivity accumulated during uptake of $\left[{ }^{14} \mathrm{C}\right] \mathrm{TMG}$ (extracted from the organisms by butanol) co-chromatographed with a reference sample of authentic $\left[{ }^{14} \mathrm{C}\right] \mathrm{TMG}$.

The mechanism of energization of the TMG transport system was investigated. It was expected that in the absence of a phosphotransferase system, the p.m.f. and/or the presence of ATP per se would be required for TMG transport. First the role of the $\Delta \psi$ was examined. Lactose-grown organisms were starved by incubation for $30 \mathrm{~min}$ with $10 \mathrm{~mm}-\mathrm{NaN}_{3}$ plus $40 \mu \mathrm{g}$ chloramphenicol ml-1 and then incubated in 50 mM-Tris/ $\mathrm{HCl}, \mathrm{pH} 6.6$ or $\mathrm{pH} 9.0$, in the presence of $100 \mathrm{mM}-\mathrm{KCl}$ and $2 \mu \mathrm{M}$-valinomycin. After incubation for $1 \mathrm{~h}$, each suspension was diluted into $\mathrm{KCl}$-free or $\mathrm{KCl}$-containing Tris/ $\mathrm{HCl}$ buffer at $\mathrm{pH} 6.6$ or $\mathrm{pH} 9 \cdot 0$ containing $10 \mathrm{mM}^{-\mathrm{NaN}_{3}}$. A diffusion potential, resulting from valinomycin-mediated $\mathrm{K}^{+}$efflux, was expected to be generated in the $\mathrm{K}^{+}$-free but not in the $\mathrm{K}^{+}$-containing suspensions. A 


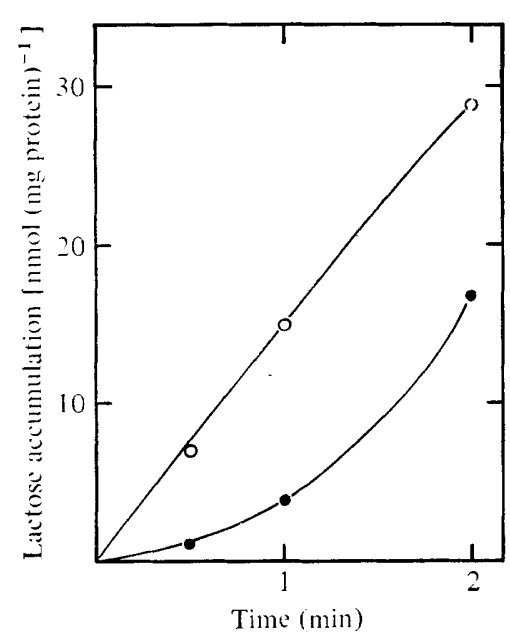

Fig. 1

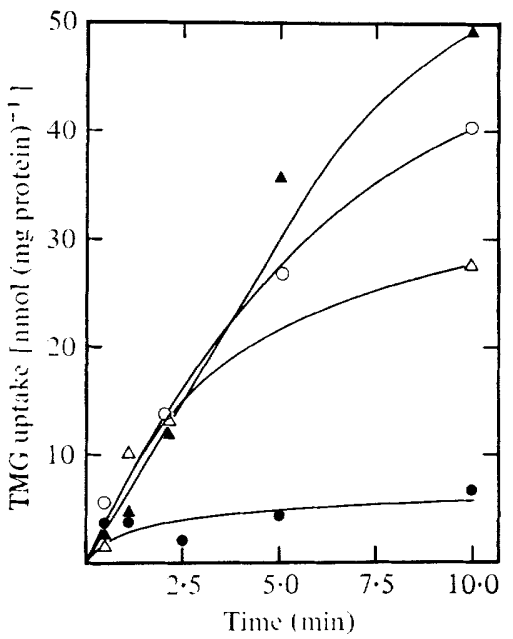

Fig. 2

Fig. 1. Lactose accumulation at $\mathrm{pH} 9.0$ in the presence or absence of an artificial electron donor. Organisms grown on PT9/lactose were assayed for lactose uptake ( $20 \mu \mathrm{M}$ final concentration) in PT9 in the absence ( $)$ or presence $(O)$ of $20 \mathrm{~mm}$-ascorbate plus $2 \mathrm{~mm}$-TMPD.

Fig. 2. Transport of TMG at pH 9.0 and $\mathrm{pH} 6.6$ in the presence or absence of an artificial electron donor. Organisms grown on PT9/lactose were assayed for TMG uptake ( $200 \mu \mathrm{M}$ final concentration) in PT9 $(\boldsymbol{\Theta}, O)$ or PT6.6 $(\Delta, \Delta)$ in the absence $(\boldsymbol{\Delta}, \boldsymbol{\Delta})$ or presence $(O, \Delta)$ of $20 \mathrm{~mm}$-ascorbate plus 2 mM-TMPD.

\section{Table 2. Specificity of TMG transport at pH $6 \cdot 6$ and $9 \cdot 0$}

Washed organisms were preincubated for $2 \mathrm{~min}$ with the indicated additions (final concentration $2 \mathrm{mM}$ ) before uptake of $\left[{ }^{14} \mathrm{C}\right.$ TTMG (final concentration $200 \mu \mathrm{M}$ ) was measured in the presence of ascorbate/TMPD. Transport of TMG by control suspensions (no additions) was $15.0 \mathrm{nmol} \mathrm{min} \mathrm{m}^{-1}$ $(\mathrm{mg} \text { protein })^{-1}$ at $\mathrm{pH} 6.6$ and $16.5 \mathrm{nmol} \mathrm{min}^{-1}(\mathrm{mg} \text { protein })^{-1}$ at $\mathrm{pH} \mathrm{9.0.}$

$\begin{array}{lcc}\text { Addition } & \text { pH 6.6 } & \mathrm{pH} \mathrm{9.0} \\ \text { Lactose } & 96 & 91 \\ \text { ONPG } & 70 & 77 \\ \text { IPTG } & 67 & 58 \\ \text { Melibiose } & 74 & 82 \\ \text { Galactose } & 46 & 60 \\ \text { Glucose } & 26 & 28 \\ \text { Cellobiose } & 24 & 20 \\ \text { Sucrose } & 26 & 12 \\ \text { Maltose } & 20 & 7 \\ \text { Methyl } \alpha \text {-glucoside } & 14 & 10 \\ \text { Mannose } & 0 & 0 \\ \text { Fructose } & 0 & 0\end{array}$

significant diffusion potential was observed at both $\mathrm{pH}$ values, as indicated by TPMP+ uptake (Fig. 3). However, the rate of TMG uptake, which was markedly lowered by the azide treatment, was not stimulated by the increase in the $\Delta \psi$.

Abolition of a transmembrane $\Delta \mathrm{pH}$ by nigericin causes an increase in the $\Delta \psi$ in isolated membrane vesicles (Ramos et al., 1976). No evidence for a proton symport mechanism for TMG uptake was found in the $B$. circulans strain; addition of TMG did not diminish the $\Delta \mathrm{pH}$ at $\mathrm{pH} 6.6$ and alkalinization of the medium did not occur concomitantly with TMG uptake (data not shown). Treatment of the organisms with nigericin abolished the $\Delta \mathrm{pH}$ at $\mathrm{pH}$ 6.6, as monitored by DMO uptake. There was a slight concomitant increase in the $\Delta \psi$, from -116 to $-128 \mathrm{mV}$, while cellular ATP levels declined from 4.8 to $1.6 \mathrm{nmol}$ (mg protein) ${ }^{-1}$. 


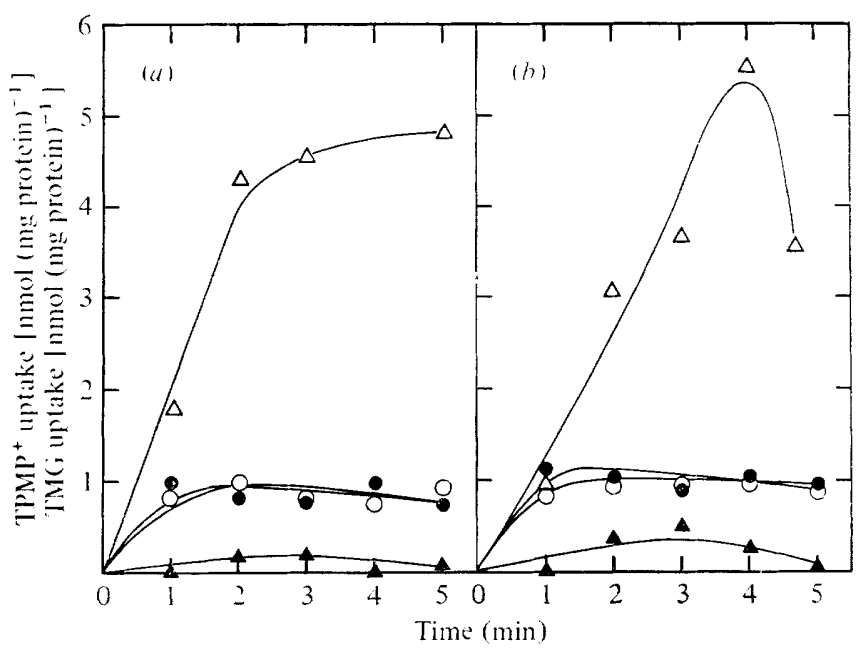

Fig. 3. Effect of valinomycin-induced $\mathrm{K}^{+}$diffusion potential on the uptake $\left.200 \mu \mathrm{M}-{ }^{14} \mathrm{C}\right] \mathrm{TMG}$ and $25 \mu \mathrm{M}-\left[{ }^{3} \mathrm{H}\right] \mathrm{TPMP} \mathrm{P}^{+}$. Organisms grown on PT9/lactose to the late-exponential phase were washedand resuspended in $50 \mathrm{~mm}$-Tris/ $\mathrm{HCl}, \mathrm{pH} 9 \cdot 0$ or $6 \cdot 6$. The suspensions were starved for $30 \mathrm{~min}$ at $30^{\circ} \mathrm{C}$ in the presence of $10 \mathrm{~mm}-\mathrm{NaN}_{3}$ and $40 \mu \mathrm{g}$ chloramphenicol ml${ }^{-1}$. The suspensions were then concentrated 100-fold by centrifugation and resuspension in $50 \mathrm{~mm}$-Tris/ $\mathrm{HCl}, \mathrm{pH} 9 \cdot 0$ or 6.6 , plus $100 \mathrm{~mm}-\mathrm{KCl}, 2 \mu \mathrm{M}$-valinomycin and $10 \mathrm{~mm}-\mathrm{NaN}_{3}$. After incubation at $30^{\circ} \mathrm{C}$ for $1 \mathrm{~h}$, the uptake experiments were initiated by a 100 -fold dilution of the suspensions into $50 \mathrm{~mm}-\mathrm{Tris} / \mathrm{HCl}$ at $\mathrm{pH}$ $9 \cdot 0(a)$ or pH $6.6(b)$, both containing $2 \mu \mathrm{M}$-valinomycin and either $100 \mathrm{~mm}-\mathrm{KCl}(\bullet, \mathbf{\Lambda})$ or $100 \mathrm{~mm}$ $\mathrm{NaCl}(O, \triangle)$, and TMG $(\bullet, \bigcirc)$ or $\operatorname{TPMP}^{+}(\Lambda, \Delta)$ uptake was assayed.

\section{Table 3. Effect of DCCD on $\triangle \psi$, cellular ATP content and TMG uptake}

Organisms grown on PT9/lactose to the late-exponential phase were washed and resuspended in either PT6.6 or PT9. Suspensions were assayed for TMG uptake ( $200 \mu \mathrm{m}$ final concentration), $\Delta \psi$ and ATP in the presence of ascorbate $(20 \mathrm{mM})$ and TMPD $(2 \mathrm{mM})$ and either with or without $100 \mu \mathrm{M}-\mathrm{DCCD} . \Delta \psi$ was determined by the distribution of $\left[{ }^{3} \mathrm{H}\right] \mathrm{TPMP}^{+}$.

\begin{tabular}{|c|c|c|c|c|c|c|}
\hline \multirow[b]{2}{*}{$\begin{array}{c}\text { External } \\
\mathrm{pH}\end{array}$} & \multicolumn{2}{|c|}{$\begin{array}{c}\text { ATP content } \\
\left.[\text { nmol (mg protein })^{-1}\right]\end{array}$} & \multicolumn{2}{|c|}{ 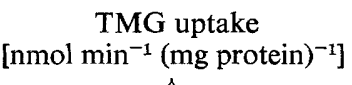 } & \multicolumn{2}{|c|}{$\Delta \psi(\mathrm{mV})$} \\
\hline & $\begin{array}{l}\text { With } \\
\text { DCCD }\end{array}$ & $\begin{array}{l}\text { Without } \\
\text { DCCD }\end{array}$ & $\begin{array}{l}\text { With } \\
\text { DCCD }\end{array}$ & $\begin{array}{l}\text { Without } \\
\text { DCCD }\end{array}$ & $\begin{array}{l}\text { With } \\
\text { DCCD }\end{array}$ & $\begin{array}{l}\text { Without } \\
\text { DCCD }\end{array}$ \\
\hline $\begin{array}{l}6 \cdot 6 \\
9 \cdot 0\end{array}$ & $\begin{array}{l}1 \cdot 04 \\
0.83\end{array}$ & $\begin{array}{l}4 \cdot 51 \\
4 \cdot 42\end{array}$ & $\begin{array}{l}1.9 \\
2 \cdot 3\end{array}$ & $\begin{array}{l}12 \cdot 7 \\
12 \cdot 8\end{array}$ & $\begin{array}{l}-82 \\
-99\end{array}$ & $\begin{array}{r}-84 \\
-125\end{array}$ \\
\hline
\end{tabular}

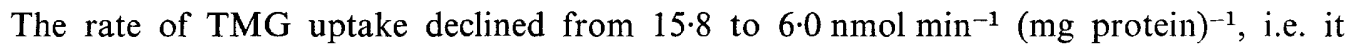
correlated with the cellular ATP levels and not with the $\Delta \psi$.

Several other observations suggested that TMG uptake was directly dependent on ATP. Organisms incubated at $\mathrm{pH} 6.6$ contained $1.17 \mathrm{nmol}$ ATP (mg protein) ${ }^{-1}$. Those treatments which facilitated TMG uptake at $\mathrm{pH} 9.0$ also raised the cellular ATP levels. Thus, preincubation with lactose, as described earlier, caused a four- to five-fold increase in the ATP levels at pH 6.6 and an eight- to nine-fold increase in the ATP levels at pH 9.0. Incubation with ascorbate/TMPD also raised the cellular ATP levels at both $\mathrm{pH} 6.6$ and 9.0 to 4.55 and $4.48 \mathrm{nmol}$ ATP (mg protein) $)^{-1}$, respectively. In the presence of ascorbate/TMPD, DCCD markedly inhibited TMG uptake; the cellular ATP levels, but not the $\Delta \psi$, were correspondingly lowered (Table 3). An effect of arsenate on cellular ATP levels could also be demonstrated; incubation with arsenate was effective only when carried out in the presence of growth substrate. Treatment of cells with arsenate in the presence of lactose did not affect the $\Delta \psi$, but prevented most or all of the increase in ATP levels that had been found previously on preincubation with lactose (Table 4). Under these conditions, the rate 
Table 4. Effect of arsenate on $\Delta \psi$, cellular ATP content and TMG uptake

Organisms grown on PT9/lactose to the late-exponential phase were washed and resuspended in $50 \mathrm{~mm}$-Tris $/ \mathrm{HCl}, \mathrm{pH} \mathrm{9.0}$. The organisms were incubated with or without $10 \mathrm{~mm}$-sodium arsenate for $10 \mathrm{~min}$ at $30^{\circ} \mathrm{C}$ in the presence of $25 \mathrm{~mm}$-lactose, trace salts, $0.1 \%(\mathrm{w} / \mathrm{v})$ yeast extract and chloramphenicol $\left(40 \mu \mathrm{g} \mathrm{ml}^{-1}\right)$. After washing and resuspending at $\mathrm{pH} 6.6$ or 9.0 , with or without arsenate, the suspensions were assayed for TMG uptake, $\Delta \psi$ and ATP. $\Delta \psi$ was determined by the distribution of $\left[{ }^{3} \mathrm{H}\right] \mathrm{TPMP}+$.

\begin{tabular}{|c|c|c|c|c|c|c|}
\hline \multirow[b]{2}{*}{$\begin{array}{l}\text { External } \\
\mathrm{pH}\end{array}$} & \multicolumn{2}{|c|}{ 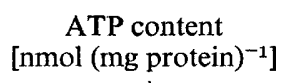 } & \multicolumn{2}{|c|}{$\begin{array}{c}\text { TMG uptake } \\
\left.\text { [nmol } \min ^{-1}(\text { mg protein })^{-1}\right]\end{array}$} & \multicolumn{2}{|c|}{$\Delta \psi(\mathrm{mV})$} \\
\hline & $\begin{array}{l}\text { With } \\
\text { arsenate }\end{array}$ & $\begin{array}{l}\text { Without } \\
\text { arsenate }\end{array}$ & $\begin{array}{l}\text { With } \\
\text { arsenate }\end{array}$ & $\begin{array}{l}\text { Without } \\
\text { arsenate }\end{array}$ & $\begin{array}{c}\text { With } \\
\text { arsenate }\end{array}$ & $\begin{array}{l}\text { Without } \\
\text { arsenate }\end{array}$ \\
\hline $\begin{array}{l}6 \cdot 6 \\
9 \cdot 0\end{array}$ & $\begin{array}{l}1.07 \\
1 \cdot 01\end{array}$ & $\begin{array}{l}4 \cdot 76 \\
4 \cdot 85\end{array}$ & $\begin{array}{l}4 \cdot 7 \\
4 \cdot 2\end{array}$ & $\begin{array}{l}13 \cdot 3 \\
11 \cdot 8\end{array}$ & $\begin{array}{r}-98 \\
-141\end{array}$ & $\begin{array}{r}-91 \\
-148\end{array}$ \\
\hline
\end{tabular}

of TMG uptake was inhibited by over $50 \%$. Prolonged incubation with arsenate caused more marked reductions in both cellular ATP and TMG uptake, but the longer treatments also caused some decrease in the $\Delta \psi$.

\section{DISCUSSION}

Little information beyond general growth characteristics is available concerning species of Bacillus that can grow at alkaline pH (Chislett \& Kushner, 1961; Kushner \& Lisson, 1959; Ohta et al., 1975). Extensive work has been done on the uptake of organic acids (Bisschop et al., 1975b) and amino acids (Bisschop et al., 1975a; Clark \& Young, 1974; Konings et al., 1971; Konings \& Freese, 1972) by B. subtilis in both whole organisms and membrane vesicles at near neutral $\mathrm{pH}$. From the present study and our previous work on $B$. alcalophilus (Guffanti et al., 1978), some possible generalizations begin to emerge. In both the true alkalophile and in the alkaline-tolerant $B$. circulans the cytoplasmic $\mathrm{pH}$ never rose above $9 \cdot 0$ to $9 \cdot 5$. It is not surprising that an upper cytoplasmic $\mathrm{pH}$ limit, compatible with life, should be in this range; both RNA stability and the $\mathrm{p} K$ values of protein amino groups would be relevant factors. The alkalophile could grow at even higher $\mathrm{pH}$ values, thus withstanding the bioenergetic constraints imposed by a reversed $\Delta \mathrm{pH}$. The alkalinetolerant species, by contrast, did not grow above $\mathrm{pH} 9 \cdot 0$ to $9 \cdot 5$, and therefore was not subject to a reversed $\Delta \mathrm{pH}$. We are currently studying two additional alkaline-tolerant Bacillus species and one newly isolated alkalophilic Bacillus species; so far the same pattern of $\mathrm{pH}$ limits vis à vis external and cytoplasmic $\mathrm{pH}$ has been found. The basis for the difference between alkalophilic and alkaline-tolerant strains, such that only the former grow at $\mathrm{pH}$ values that necessitate maintenance' of a reversed $\Delta \mathrm{pH}$, may include such factors as antiporters which can establish a high $\Delta \psi$ at very alkaline $\mathrm{pH}$ values and enzymes for ATP synthesis, which, in the alkalophile, would have to function under conditions in which there was a negligible p.m.f. (Guffanti et al., 1978). It is notable that both the alkaline-tolerant $B$. circulans and B. alcalophilus (Guffanti et al., 1978) exhibited a rise in $\Delta \psi$ as the external $\mathrm{pH}$ was raised. By contrast, the $\Delta \psi$ of Escherichia coli (Padan et al., 1976) and Arthrobacter pyridinolis (K. G. Mandel \& T. A. Krulwich, unpublished results), which grow at neutral $\mathrm{pH}$, remain constant over a range of $\mathrm{pH}$.

The transport system for TMG in the alkaline-tolerant strain of $B$. circulans was clearly an active transport system which involved accumulation of the substrate, against a concentration gradient, by a saturable carrier dependent upon metabolic energy. The approximately 180-fold concentration of TMG above the external concentration compared favourably with TMG accumulation by $E$. coli (Winkler \& Wilson, 1966). The transport system for TMG in $B$. circulans displayed an affinity for lactose, other $\beta$-galactosides and the $\alpha$-galactoside melibiose, a specificity similar to that of the lactose permease system in $E$. coli (Kennedy, 1970). 
Since $B$. circulans is an aerobe, it was particularly difficult to separate the p.m.f. and ATP as necessary sources of energy for transport. Several lines of evidence, however, indicated a direct requirement for ATP: (1) generation of a $\Delta \psi$ in starved organisms was not accompanied by a stimulation of TMG transport; (ii) treatment of cells with nigericin at $\mathrm{pH} 6.6$ abolished the $\Delta \mathrm{pH}$ with a concomitant increase in the $\Delta \psi$, while cellular ATP levels and the rate of TMG uptake were lowered; (iii) those conditions which facilitated transport at $\mathrm{pH} 9 \cdot 0$, i.e. preincubation with lactose or addition of ascorbate/TMPD, raised cellular ATP levels correspondingly; (iv) the stimulation of TMG transport by ascorbate/TMPD was abolished by DCCD, an ATPase inhibitor; and (v) treatment of cells with arsenate under conditions in which the $\Delta \psi$ was unaffected, lowered both the levels of cellular ATP and the rate of TMG transport. However, none of these experiments ruled out the possibility that a p.m.f. might be required for TMG transport in addition to ATP.

We thank Dr J. Wetmur for determining the G + C content of DNA and Dr H. R. Kaback for advice on the use of the flow dialysis apparatus. This work was supported by research grants AM14663 from the National Institutes of Health and GB 20481 from the National Science Foundation of the U.S.A. Dr Krulwich is the recipient of a Research Career Development Award from the National Institutes of Health. Dr Guffanti is a trainee on Institutional Training Grant GM 07036.

\section{REFERENCES}

Berger, E. A. (1973). Different mechanisms of energy coupling for the active transport of proline and glutamine in Escherichia coli. Proceedings of the National Academy of Sciences of the United States of America 70, 1514-1518.

Berger, E. A. \& Heppel, L. A. (1974). Different mechanisms of energy coupling for the shocksensitive and shock-resistant amino acid permeases of Escherichia coli. Journal of Biological Chemistry 249, 7747-7755.

Bisschop, A., DE Jong, L., Lima Costa, M. E. \& KoNINGS, W. N. (1975a). Relation between reduced nicotinamide adenine dinucleotide oxidation and amino acid transport in membrane vesicles from Bacillus subtilis. Journal of Bacteriology 121, 807813.

Bisschop, A., Doddema, H. \& Konings, W. N. $(1975 b)$. Dicarboxylic acid transport in membrane vesicles from Bacillus subtilis. Journal of Bacteriology 124, 613-622.

Buchanan, R. E. \& Gibbons, N. E. (editors) (1974). Bergey's Manual of Determinative Bacteriology, 8th edn. Baltimore: Williams \& Wilkins.

Chislett, M. E. \& Kushner, D. J. (1961). A strain of Bacillus circulans capable of growing under highly alkaline conditions. Journal of General Microbiology 24, 187-190.

Clark, V. L. \& Young, F. E. (1974). Active transport of $\mathrm{D}$-alanine and related amino acids by whole cells of Bacillus subtilis. Journal of Bacterio$\log y$ 120, 1085-1092.

Cole, H., Wimpenny, J. W. T. \& Hughes, D. E. (1967). The ATP pool in Escherichia coli. I. measurement of the pool using a modified luciferase assay. Biochimica et biophysica acta 143, 445-453.

Egan, G. \& Morse, M. L. (1966). Carbohydrate transport in Staphylococcus aureus: Studies on the transport process. Biochimica et biophysica acta 112, 63-73.

FlaGG, J. L. \& Wilson, T. H. (1977). A protonmotive force as the source of energy for galactoside transport in energy-depleted Escherichia coli. Journal of Membrane Biology 31, 233-255.

Gordon, R. E., Haynes, W. C. \& Hor-NAY PANG, C. (1973). The genus Bacillus. Agriculture Handbook No. 427. Washington D.C.: U.S. Department of Agriculture.

Guffanti, A. A., Susman, P., Blanco, R. \& KrulWICH, T. A. (1978). The protonmotive force and $\alpha$-aminoisobutyric acid transport in an obligately alkalophilic bacterium. Journal of Biological Chemistry 253, 708-715.

Hegeman, G. D. (1966). Synthesis of the enzymes of the mandelate pathway by Pseudomonas putida. I. Synthesis of enzymes by the wild type. Journal of Bacteriology 91, 1140-1154.

HertzberG, E. L. \& Hinkle, P. C. (1974). Oxidative phosphorylation and proton translocation in membrane vesicles prepared from Escherichia coli. Biochemical and Biophysical Research Communications 58, 178-184.

Kashket, E. R. \& Wilson, T. H. (1974). Protonmotive force in fermenting Streptococcus lactis 7962 in relation to sugar accumulation. Biochemical and Biophysical Research Communications 59, 879-885.

KenNedy, E. P. (1970). The lactose permease system of Escherichia coli. In The Lactose Operon, pp. 4992. Edited by J. R. Beckwith \& D. Zipser. New York: Cold Spring Harbor Laboratory.

KleIN, W. L. \& BOYER, P. D. (1972). Energization of active transport by Escherichia coli. Journal of Biological Chemistry 247, 7257-7265.

Konings, W. N. \& Freese, E. (1972). Amino acid 
transport in membrane vesicles of Bacillus subtilis. Journal of Biological Chemistry 247, 2408-2418.

Konings, W. N., Barnes, E. M. \& Kaback, H. R. (1971). Mechanisms of active transport in isolated membrane vesicles. III. The coupling of reduced phenazine methosulfate to the concentrative uptake of $\beta$-galactosides and amino acids. Journal of Biological Chemistry 246, 5857-5861.

Kushner, D. J. \& Lisson, T. A. (1959). Alkali resistance in a strain of Bacillus cereus pathogenic for the Larch Sawfly Pristiphora erichsonii. Journal of General Microbiology 21, 96-108.

Larsen, S. H., Adler, J., Gargus, J. J. \& HogG, R. W. (1974). Chemomechanical coupling without ATP: the source of energy for motility and chemotaxis in bacteria. Proceedings of the National Academy of Sciences of the United States of America 71, 1239-1243.

Lowry, O. H., Rosebrough, N. J., Farr, A. L. \& RANDALL, R. J. (1951). Protein measurement with the Folin phenol reagent. Journal of Biological Chemistry 193, 265-275.

Maloney, P. C., Kashiet, E. R. \& Wilson, T. H. (1974). A proton motive force drives ATP synthesis in bacteria. Proceedings of the National Academy of Sciences of the United States of America 71, 3896-3900.

Maloney, P. C., Kashiet, E. R. \& Wilson, T. H. (1975). Methods for studying transport in bacteria. In Methods in Membrane Biology, vol. 3, pp. 1-49. Edited by E. D. Korn. New York: Plenum Press.

MARMUR, J. (1961). A procedure for the isolation of deoxyribonucleic acid from microorganisms. Journal of Molecular Biology 3, 208-218.

MARMur, J. \& Doty, P. (1959). Heterogeneity in deoxyribonucleic acids. I. Dependence on composition of the configurational stability of deoxyribonucleic acids. Nature, London 183, 1427-1429.

Mitchell, P. (1961). Coupling of phosphorylation to electron and hydrogen transfer by a chemiosmotic type of mechanism. Nature, London 191, 144-148.

Mitchell, P. (1963). Molecule, group and electron translocation through natural membranes. Biochemical Society Symposia 22, 142-168.

Oнta, K., Kiyomiya, A., Koyana, N. \& Nosoh, Y. (1975). The basis of the alkalophilic property of a species of Bacillus. Journal of General Microbiology 86, 259-266.

Padan, E., Zilberstein, D. \& Rottenberg, $H$. (1976). The proton electrochemical gradient in Escherichia coli cells. European Journal of Biochemistry 63, 533-541.

Pavlasova, E. \& Harold, F. M. (1968). Energy coupling in the transport of $\beta$-galactosides by Escherichia coli: effect of proton conductors. Journal of Bacteriology 98, 198-204.

Ramos, S. \& KABACK, H. R. (1977a). The electrochemical proton gradient in Escherichia coli membrane vesicles. Biochemistry 16, 848-854.
Ramos, S. \& Kaback, H. R. (1977b). The relationship between the electrochemical proton gradient and active transport in Escherichia coli membrane vesicles. Biochemistry 16, 854-859.

Ramos, S., SChuldiner, S. \& KABACK, H. R. (1976). The electrical gradient of protons and its relationship to active transport in Escherichia coli membrane vesicles. Proceedings of the National Academy of Sciences of the United States of America 73, 1892-1896.

Scholes, P. \& Mitchell, P. (1970). Respirationdriven proton translocation in Micrococcus denitrificans. Journal of Bioenergetics 1, 1882-1884.

SChuldineR, S. \& KabACK, H. R. (1975). Membrane potential and active transport in membrane vesicles from Escherichia coli. Biochemistry 14, 5451-5461.

Stanley, P. E. \& Williams, S. G. (1969). Use of the liquid scintillation spectrometer for determining adenosine triphosphate by the luciferase enzyme. Analytical Biochemistry 29, 381-392.

Tanaka, S., Lerner, S. A. \& Lin, E. C. C. (1967). Replacement of a phosphoenolpyruvate-dependent phosphotransferase by a nicotinamide adenine dinucleotide-linked dehydrogenase for the utilization of mannitol. Journal of Bacteriology 93, 642-648.

Thipoyathasana, P. \& Valentine, R. C. (1974). The requirement for energy transducing ATPase for anaerobic motility in Escherichia coli. Biochimica et biophysica acta 347, 464 468 .

Tsuchiya, T. (1977). Adenosine 5'-triphosphate synthesis driven by a protonmotive force in membrane vesicles of Escherichia coli. Journal of Bacteriology 129, 763-769.

Tsuchiya, T. \& Rosen, B. P. (1976). Adenosine 5 -triphosphate synthesis energized by an artificially imposed membrane potential in membrane vesicles of Escherichia coli. Journal of Bacteriology 127, 154-161.

WadDell, W. J. \& Butler, T. C. (1959). Calculation of intracellular $\mathrm{pH}$ from the distribution of 5,5-dimethyl-2,4-oxazolidinedione (DMO): application to skeletal muscle of the dog. Journal of Clinical Investigation 38, 720-729.

West, I. C. \& Mitchell, P. (1972). Proton-coupled $\beta$-galactoside translocation in non-metabolizing Escherichia coli. Journal of Bioenergetics 3, 445462.

West, I. C. \& Mitchell, P. (1974). The protontranslocating ATPase of Escherichia coli. FEBS Letters 40, 1-4.

Wilson, D. M., Alderete, J. F., Maloney, P. C. \& WILSON, T. H. (1976). Protonmotive force as the source of energy for adenosine 5'-triphosphate synthesis in Escherichia coli.Journal of Bacteriology 126, 327-337.

WinkLeR, H. H. \& Wilson, T. H. (1966). The role of energy coupling in the transport of $\beta$-galactosides by Escherichia coli. Journal of Biological Chemistry 241, 2200-2211. 